\title{
S I 00A4 overexpression proves to be independent marker for breast cancer progression
}

\author{
Nawfal I Ismail, Gurjeet Kaur, Hasnah Hashim and Mohammed S Hassan*
}

Address: Advanced Medical and Dental Institute (AMDI), Universiti Sains Malaysia (USM), Penang, Malaysia

Email: Nawfal I Ismail - nofal_ishahad@yahoo.com; Gurjeet Kaur - gurjeet@amdi.usm.edu.my; Hasnah Hashim - hasnah@amdi.usm.edu.my;

Mohammed S Hassan* - mshassan1950@yahoo.com

* Corresponding author

Published: 5 September 2008

Cancer Cell International 2008, 8:12 doi:10.1 I86/1475-2867-8-12

This article is available from: http://www.cancerci.com/content/8/I/I2

(c) 2008 Ismail et al; licensee BioMed Central Ltd.

This is an Open Access article distributed under the terms of the Creative Commons Attribution License (http://creativecommons.org/licenses/by/2.0), which permits unrestricted use, distribution, and reproduction in any medium, provided the original work is properly cited.
Received: 30 May 2008

Accepted: 5 September 2008

\begin{abstract}
Background: Breast cancer is the most common cancer and cause of deaths in women around the world. Oncogene amplification usually occurs late in tumor progression and correlates well with aggressiveness of tumor. In fact the function of the SI00A4 protein and its role in metastasis is unclear at present. The purpose of the study was to determine the expression of SI00A4 protein in the invasion status and metastatic potential of breast cancer by using tissue microarray and to determine its role in breast cancer based on the expression of SI00A4 gene product.
\end{abstract}

Methods: SI00A4 protein expression was examined by immunohistochemistry (IHC) using commercially available tissue microarray containing malignant and normal breast tissue cores from 216 patients.

Results: SI00A4 was absent in normal breast tissues while positive in $45.1 \%$ of infiltrating ductal carcinoma (IDC) node negative and $48.8 \%$ of infiltrating lobular carcinoma node negative. In paired samples, SIO0A4 protein was expressed in $13.5 \%$ of IDC node positive cases and $35.1 \%$ of matched lymph node metastasis.

Conclusion: SI00A4 protein expression appears widely expressed in early and advanced breast cancer stages compared with normal breast. Our study suggests SI00A4 may play a role in breast cancer progression and may prove to be an independent marker of breast cancer which appears to be down regulated in more advanced stages of breast cancer.

\section{Background}

Breast cancer is still the most common public health problem in women worldwide [1]. Cancer cells may invade the surrounding by tissue remodeling and angiogenesis [2-7]. They may spread through the bloodstream and lymphatic system to other parts of the body [2-7]. The majority of invasive breast cancer from the epithelium of lobules and ducts of the glands [8-21]. Metastasis is considered as the spreading of tumor cells from the primary neoplasm to distant sites $[22,23]$. In spite of significant advancement in early diagnosis, surgical intervention as well as local and systemic adjuvant therapies, the majority of cancer deaths are attributable to metastasis that are resistant to available therapies [22].

The metastasis process is not a random process but consist of a complex series of linked and interrelated steps involving multiple host-tumor interaction [24]. Many proteins 
including proteases, adhesion molecules, angiogenesis, and growth factor are involved in metastasis [25]. Therefore, understanding the gene and protein expression changes in metastatic cancer cells and nearby cells of the microenvironment may aid in early diagnosis and therapeutic intervention. During the last decade, considerable progress has been made in understanding these changes at the molecular level. In fact most deaths of women with breast cancer arise not as a result of primary tumor but from its metastatic spread to distant sites in the body $[26,27]$. Once spread and secondary masses are formed, breast cancers are usually incurable [28]. Yet a sensitive and reliable method for early metastasis in breast cancer is still not available.

Breast cancer is considered to be a systemic disease this would mean that the most breast carcinoma metastasize before diagnosis of the primary lesion [29]. Therefore, early detection of metastasized lesion and identification of more effective therapeutic modalities for metastatic disease are necessities if the prognosis for patients with advanced breast cancer is to improve.

The S100 gene family located on chromosome 1q21, comprises more than 20 members whose protein sequences encompass at least one EF-hand $\mathrm{Ca}++$ binding motif [30,31]. S100 is a $21 \mathrm{Kd}$ highly acidic and water soluble calcium binding protein [32]. S100A4 gene occurs in cluster of 13 S100 genes on chromosome 1 [33], which are also often amplified in cancer of the breast and which contains jumping elements [34]. The expression of individual family members is not permanent for all tissues and appears to be an element of tissue specific expression. S100A4 is composed of an alpha and beta chain with molecular weight of $10-12 \mathrm{Kd}$ [35]. It is a small molecule and can pass through the nuclear pores without any active transport mechanism being involved. S100A4 binds and inhibits phosphorylation of the p53 C-terminal peptide by protein kinase $\mathrm{C}$. The tumor suppressor protein p53 has also been identified as an S100A4 interacting protein and may provide a link between S100A4 and apoptosis [36]. p53 is a critical tumor suppressor that is involved in most if not all tumorigenesis. Almost $30-50 \%$ of breast cancers contain a p53 mutation [37]. Other reported S100A4 interacting proteins include tropomyosin, methionine aminopeptidase, and CCN3 (cysteine-rich $61 /$ connective tissue growth factor/nephroblastoma overexpressed) [38-40].

Studies to determine the mechanistic basis for S100A4 function have shown a potential role for S100A4 in several different facts of tumor progression including motility, invasion, and apoptosis [[36,41], and [42]]. It has also been reported that extracelluar secreted S100A4 can affect cell differentiation and migration [42-44]. Elevated levels of immunocytochemically detected S100A4 are associated with the more malignant carcinomatous regions of the primary tumor and with liver metastasis [45]. An increase in S100A4 protein expression has been correlated with a worse prognosis for patients with different types of cancer including colorectal, gallbladder, bladder, esophageal, breast, and non small lung cancer [46-52]. The main purpose of the study was to find the expression pattern of S100A4 proteins in different types of breast cancer with or without lymph node involvement and to determine its role in breast cancer using tissue microarray.

\section{Methods}

Formalin-fixed paraffin-embedded tissue microarrays from 188 lymph node negative breast cancer patients, 50 breast cancer patients with lymph node metastasis (50 malignant tissues and 50 matched lymph node tissue cores with metastasis) and 8 normal breast tissue cores were analyzed by immunohistochemistry for the expression S100A4 protein. Included in this study were patients with infiltrating ductal carcinoma, infiltrating lobular carcinoma, normal breast tissue and lymph node metastasis. The final number was 122 tissue cores of node negative infiltrating ductal carcinoma, 41 node negative infiltrating lobular carcinoma, seven normal breast tissue, 40 node positive (38 infiltrating ductal carcinoma, 2 infiltrating lobular carcinoma) and 46 tissue cores of lymph node metastasis. We did not evaluate infiltrating lobular carcinoma node positive because of the low sample size (2 cases). Forty six tissue cores were excluded from statistics because very little cancer cells or no breast cancer tissue were seen. The total number after exclusion was 254 tissue cores (37 matched tissues) of 216 patients.

\section{Immunohistochemistry (IHC)}

Rabbit Anti-Human polyclonal primary antibody against S100A4 protein (Code No. A5114, from DakoCytomation, Denmark) was used on deparaffinized tissue microarray slides (Cat. No. BR 2001, BR 1001 from Biomax, USA). A secondary detection system (DAKO Envision) enhanced with conjugated polymer was used to bind with the primary antibody. DAB chromogen was used for permanent color development and detection under microscope.

The percentage of carcinoma cells with cytoplasmic/membranous/nuclear staining was recorded on each specimen at 200× magnification, using light microscope. The expression of S100A4 was scored in all tumors as: positive $\geq 5 \%$ and negative $<5 \%$ stained cells. Also the intensity of staining was categorized into three groups: weak, moderate and strong. This was ascertained by a single qualified pathologist. 
A tissue section of breast cancer was used as positive control for S100A4. Rabbit IgG isotype (Sigma-Aldrich, USA) was used instead of primary antibody in the immunohistochemical technique on a tissue section each of breast cancer and normal breast as negative control (Figure 1).

The tissue microarray slides were placed on hot plate at $60^{\circ} \mathrm{C}$ for 30 minutes. The slides were immersed in two changes of xylene. Slides were then immersed in 3 different concentrations of ethanol. Slides were rinsed with distilled water to remove ethanol. The slides were then placed in target retrieval solution EDTA buffer pH 9.0 (DAKO) and heated on microwave. Slides were allowed to cool at room temperature and rinsed with Tris Buffered saline (TBS) mixed with tween 20. Slides were covered with peroxidase blocking solution (DAKO), followed by rinsing with TBS buffer mixed with tween 20 . Then $200 \mu \mathrm{l}$ of primary antibody (dilution 1:200) was added on the tissue microarray slides, followed by rinsing with TBS mixed with tween 20. Two drops of DAKO Envision/HRP, Rabbit/Mouse (secondary antibody) were added on the slides, followed by rinsing with TBS mixed with tween 20. After that DAB substrate (DAKO) was added on section slides followed by rinsing, immersion into hematoxylin and 4 different concentrations of ethanol. After that slides were immersed in two changes of xylene and cover slipped. All incubation steps after heat induced epitope retrieval were carried at room temperature.

\section{Results}

The S100A4 protein was expressed in the cell cytoplasm without evidence of nuclear staining.

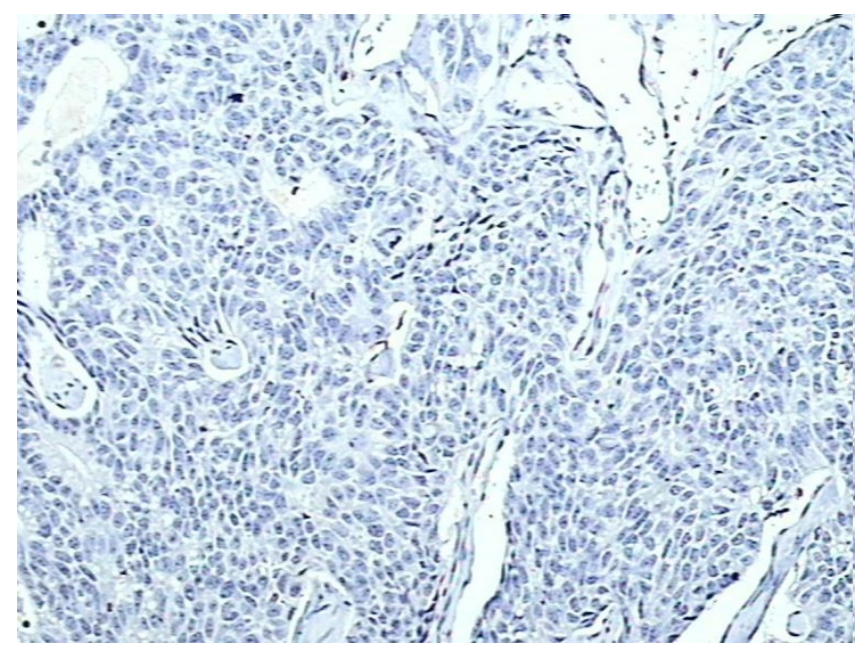

Figure I

Negative control, SI 00A4 protein immunohistochemical staining in breast cancer tissue, showing absent staining $(\times 200)$.
There were a total of 122 cases of infiltrating ductal carcinoma node negative and 41 cases of infiltrating lobular carcinoma node negative. Infiltrating ductal carcinoma node positive consisted of 38 cases. Thirty seven cases had paired primary infiltrating ductal carcinoma tissue with its matched lymph node core. There were also 9 cases of unrelated lymph node cores containing metastatic deposits.

A positive expression of S100A4 was observed in $45.1 \%$ (55/122) cases of infiltrating ductal carcinoma node negative (Figure 2) and $48.8 \%$ (20/41) cases of infiltrating lobular carcinoma node negative (Figure 3). S100A4 staining was not observed in normal breast tissues (Figure 4).

Five of $37(13.5 \%)$ cases in the paired samples (primary breast carcinoma and matched lymph nodes) showed presence of S100A4 protein in the primary site, while 13/ 37 (35.1\%) cases showed S100A4 in lymph node (Figure 5).

It was observed that 12 of $17(70.5 \%)$ paired cases (primary breast cancer with matched lymph node) showed expression of S100A4 in the lymph node metastasis with absent expression in the primary site. Four (23.5\%) cases showed S100A4 expression in the primary breast carcinoma with absent expression in its matched lymph node metastasis. One case showed S100A4 expression in both sites.

\section{Discussion}

Cancer is a disease or disorder characterized by uncontrolled growth (division) of the cells [53-55] and their

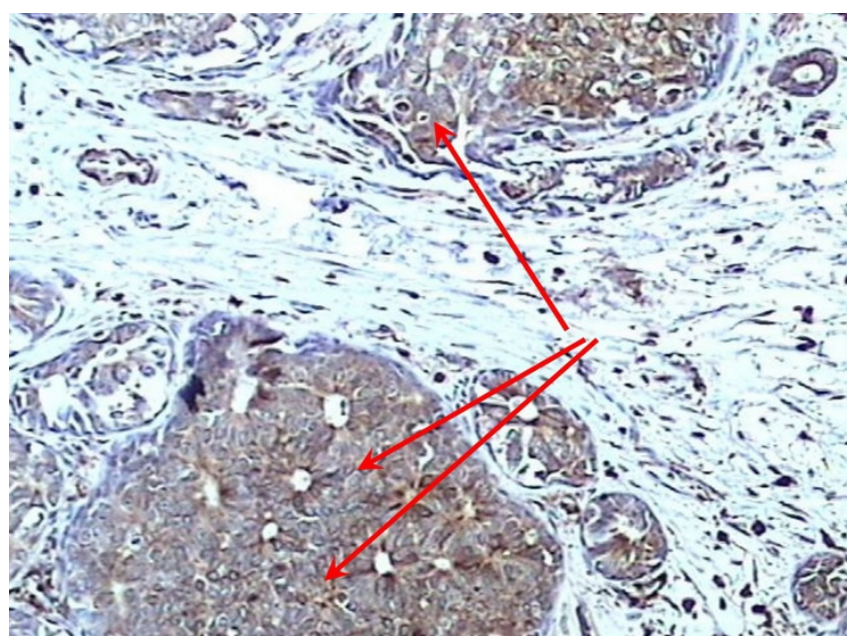

Figure 2

Positive expression of SIOOA4 within infiltrating ductal carcinoma node negative $(\times 200)$. 


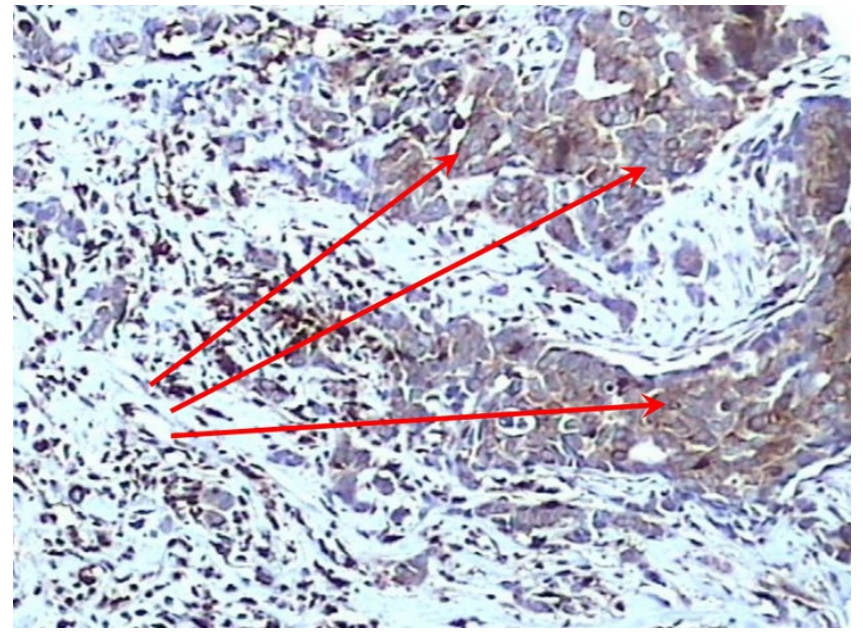

Figure 3

Positive expression of S I 00A4 within infiltrating lobular carcinoma node negative $(\times 200)$.

ability to invade other organ or tissue, either by invasion or metastasis [54-56]. Although there are many types of cancer, all cancer types begin with uncontrolled growth of abnormal single cells in the body [55]. Oncogene amplification usually occurs late in tumor progression and correlates well with aggressiveness of tumor [57]. The function of the S100A4 protein and its role in metastasis is unclear at present. It has been reported that S100A4 may affect the function of cytoskeletal proteins including actin and non muscle myosin $[58,59]$ so it is possible that S100A4 may regulate cell shape and or motility. It was reported that over expression of S100A4 protein is closely

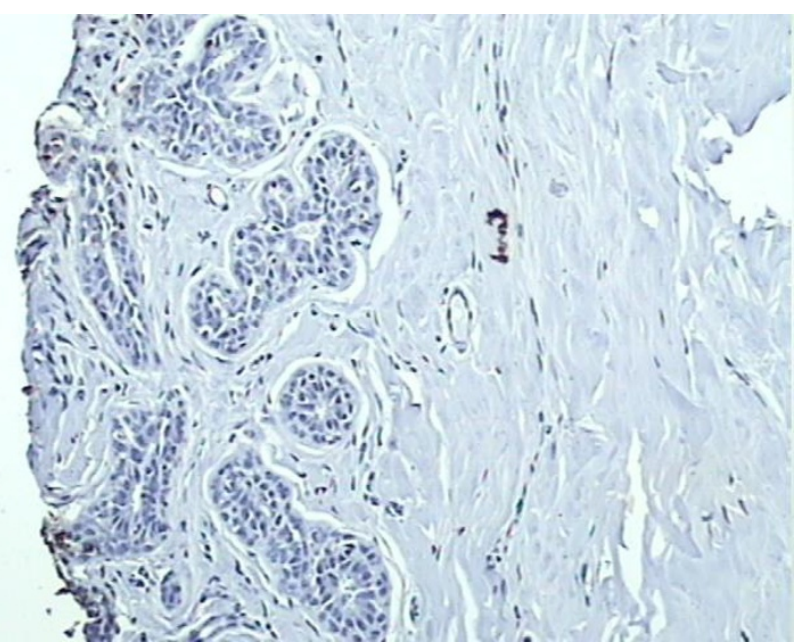

Figure 4

Negative expression of S I00A4 protein within normal breast tissues $(\times 200)$.

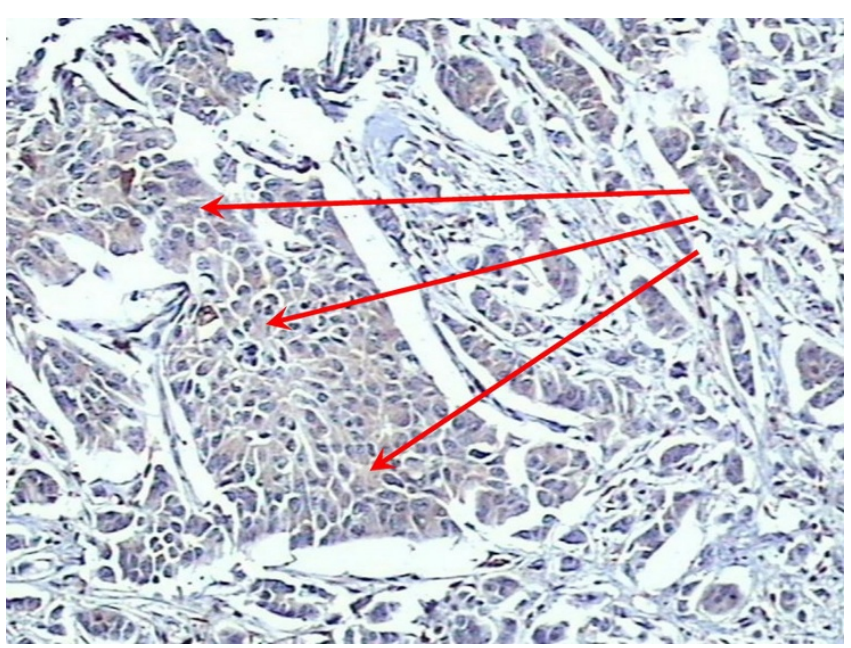

Figure 5

Positive expression of SI 00A4 within matched lymph node metastasis $(\times 200)$.

correlated with many functions for tumor aggressiveness, such as lymph node metastasis [60].

In the present study, S100A4 protein expression was examined by immunohistochemistry in infiltrating ductal, infiltrating lobular carcinoma and lymph node metastasis and their relation to tumor promotion and progression. Positive expression of S100A4 was observed in $45.1 \%$ of the infiltrating ductal carcinoma node negative cases, while in infiltrating lobular carcinoma with node negative, the expression of S100A4 protein was observed in $48.8 \%$. This shows that S100A4 has a similar expression level in both infiltrating ductal carcinoma and infiltrating lobular carcinoma with node negative. S100A4 staining was not observed in normal breast tissues. S100A4 was expressed in a higher percentage in breast cancer tissue compared to normal tissue which showed direct correlation of S100A4 protein in infiltrating breast cancer node negative. This suggests that S100A4 is over expressed in infiltrating breast carcinoma compared to normal breast. Positive expression of S100A4 protein was observed only in $13.5 \%$ of cases of infiltrating ductal carcinoma node positive while positive expression of S100A4 protein was observed in $35.1 \%$ of matched lymph node metastasis. These results showed there was a decrease in expression of S100A4 in infiltrating ductal carcinoma node positive $(13.5 \%)$ compared with IDC node negative (45.1\% positive staining), but interestingly there is an increase of expression of S100A4 protein at metastatic lymph node site. This suggests S100A4 may play a role in advanced breast cancer especially with lymph node metastasis. It was also interesting to note that the expression was seen in one site i.e. either primary tumor or its metastatic lymph node only. 
The majority $(70 \%, 12 / 17)$ of paired samples showed that when there was a positive expression of S100A4 protein in metastatic lymph node, there was associated negative expression in the primary tumor (infiltrating ductal carcinoma) of the same patient. One case showed positive expression in both primary tumor and its metastatic lymph node at the same time. This was comparable with another study which showed that S100A4 over expression directly correlated with tumor progression [60]. This study found that S100A4 was expressed in more cases of metastatic lymph node $(35.1 \%$ cases $)$ compared to matched infiltrating ductal carcinoma node positive (13.5\% cases). These results show that there was a decrease expression of S100A4 protein in the primary tumor and increase expression in the metastatic lymph node for the same patient. This suggests that S100A4 is highly expressed in newly growing cancer either in the primary or metastatic sites. S100A4 protein was expressed in the cytoplasm of node negative IDC and ILC, whereas decreased in more advanced cancer (node positive). The reduction in S100A4 expression in the primary site may probably be related to cancer cells in the process of migration to distant sites.

\section{Conclusion}

In conclusion S100A4 protein expression appears to be expressed widely in early and advanced stages of breast cancer compared with normal breast. This study indicates a complex role of S100A4 in breast cancer of different types and stages. The difference in the expression of S100A4 protein suggests it may be useful as an independent marker of breast cancer which appears to be down regulated in more advanced stages of breast cancer. However a larger study with more ILC and metastatic cases may clarify the role and function of S100A4 in breast cancer progression.

\section{Abbreviations}

IHC: Immunohistochemistry; IDC: Infiltrating ductal carcinoma; ILC: Infiltrating lobular carcinoma.

\section{Authors' contributions}

NII carried out Immunohistochemical part of the study and lab work, participated in drafting the manuscript. GK carried out the pathological part of the study, participated in drafting the manuscript. HH performed the statistical analysis. MSH initiated the project, participated in drafting the manuscript. All authors read and approved this manuscript.

\section{Acknowledgements}

I would like to thank Advanced Medical and Dental Institute (AMDI) for financial assistance and use of laboratory facilities. Also l'd like to extend my thanks to the AMDI diagnostic laboratory staff especially Puan Mariam Azmi and Encik Yahaya Osman for their technical expertise. Finally l'd like to thank all of my family for their support in happiness and sorrow.

\section{References}

I. Pencil SD, Toh Y, Nicolson GL: Candidate metastasis-associated genes of the rat 13762 NF mammary adenocarcinoma. Breast Cancer Res Treat 1993, 25:165-174.

2. Greider $\mathrm{CW}$, Blackburn $\mathrm{EH}$ : Telomeres, telomerase and cancer. Scientific American 1996, 274:80-85.

3. Paula K, Marx J: The unstable path to cancer. Science 2002, 297:558|-543.

4. Coleman WB, Tsongalis Gregory J: The molecular basis of human Cancer. Humana Press 2002:70-77.

5. Aguda BD, Friedman A: Tutorials in mathematical biosciences III: Cell Cycle, Proliferation, and Cancer. Springer; 2006:80-89.

6. Hansen HHH: Textbook of Lung Cancer: The International association for the study of lung cancer. Informa Health Care 2000:30-44.

7. Manni A: Endocrinology of breast cancer. Humana Press 1999: 160-168.

8. Eneroth CM, Franzen S, Zajicek J: Aspiration biopsy of salivary gland tumors. A critical review of 910 biopsies. Acta Cytol 1967, I I(6):470-2.

9. Frankenthaler RA, Luna MA, Lee SS: Prognostic variables in parotid gland cancer. Arch Otolaryngol Head Neck Surg 199I, I I 7(I I): I25I-6.

10. Illes RW, Brian MB: A review of the tumors of the salivary gland. Surg Gynecol Obstet 1986, I63(4):399-404.

II. Johns ME: Parotid cancer: A rational basis for treatment. Head Neck Surg 1980, 3(2): |32-41.

12. Laforga JB: Mucoepidermoid carcinoma of the parotid gland [letter]. Acta Cytol 1999, 43(3):5।5-7.

I3. O'Brien CJ, Soong SJ, Herrera GA: Malignant salivary tumorsanalysis of prognostic factors and survival. Head Neck Surg 1986, 9(2):82-92.

14. Pinkston JA, Cole P: Incidence rates of salivary gland tumors: results from a population based study. Otolaryngol Head Neck Surg 1999, I 20(6):834-40.

15. Rice DH, Becker T: Magnetic resonance imaging of the salivary glands: A comparison with computed tomographic scanning. Arch Otolaryngol Head Neck Surg 1987, I I 3( I):78-80.

16. Shikhani A, Samara M, Allam C: Primary lymphoma in the salivary glands: report of five cases and review of the literature. Laryngoscope 1987, 97( (12): |438-42.

17. Skolnik EM, Friedman M, Becker S: Tumors of the major salivary glands. Laryngoscope 1977, 87(6):843-6I.

18. Snyderman NL, Johnson JT: Salivary gland tumors: Diagnostic characteristics of the common types. Postgrad Med 1987, 82(5): 105-8. II0-2.

19. Spiro RH: Salivary neoplasms: overview of a 35-year experience with 2,807 patients. Head Neck Surg 1986, 8(3): I77-84.

20. Stafford ND, Wilde A: Parotid cancer. Surg Oncol 1997, 6(4):209-13.

21. Suzuki M, Ichimiya I, Matsushita F, Mogi G: Histological features and prognosis of patients with mucoepidermoid carcinoma of the parotid gland. J Laryngol Otol 1998, I I 2( I 0):944-7.

22. Jiang WG, Mansel RE: Biology: Cancer metastasis, Molecular and cellular mechanisms and clinical intervention. Springer; 2000: $1-12$.

23. Balducci L, Extermann M: Biological basis of geriatric oncology. Springer; 2005:10-20.

24. Liefers GJ, Cleton-Jansen AM, velde CJ van de, van Krieken JH, Cornelisse C], Tollenaar RA: Micrometastasis and survival in stage II colorectal cancer. N Engl J Med 1998, 339:223-228.

25. Page $M$ : Tumor targeting in cancer therapy. Humana Press 2002:430-444.

26. Pitot HC, Loeb DD: Fundamentals of oncology. Informa Health Care 2002:133-150.

27. Warshawsky D: Molecular carcinogenesis and the molecular biology of human cancer. CRC Press; 2006:I78-192.

28. Georgiev DB, Manassiev NA: Effect of Long - term continuous combined hormone replacement therapy with estradiol valerate and either dienogest or norethisterone acetate on mammographic density in postmenopausal women. Medscape Womens Health 2002, 7(4): I.

29. Riordan J, Auerbach K: Breastfeeding and human lactation. 2nd edition. Jones and Bartlett. London: From Midwifery Matters; 1999. 
30. Schafer BW, Heizmann CW: The SI00 family of EF-hand calcium-binding proteins: functions and pathology. Trends biochem Sci 1996, 2 I: I34-140.

31. Kim EJ, Helfman DM: Characterization of the metastasis-associated protein, SI00A4. Role of calcium binding and dimerization in cellular localization and interaction with myosin. J Biol Chem 2003, 278(32):30063-30073.

32. Mani RS, Shelling JG, Sykes BD, Kay CM: Spectral Studies on the Calcium Binding Properties of Bovine Brain S- I 00b Protein Biochemistry. 1983, 22(7): |734-40.

33. Engelkamp D, Schafer BW, Mattei MG, Erne P, Heizmann CW: Six SI00 genes are clustered on human chromosome Iq2I: Identification of two genes coding for the two previously unreported calcium-binding proteins SIOOD and SIOOE. ProC Natl Acad Sci USA 1993, 90:6547-655I.

34. Devilee P, van Vliet M, Bardoel A, Kievits T, Kuipers-Dijkshoorn N, Pearson P, Crnelisse C: Frequent somatic imbalance of marker alleles for chromosome $I$ in human primary breast carcinoma. Cancer Res 1991, 5 I:1020-1025.

35. Pedrocchi M, Schafer Bw, Durussel I, Cox JA, Heizmann CW: Purification and characterization of the recombinant human calcium-binding S100 proteins CAPL and CACY. Biochemistry 1994, 33:6732-6738.

36. Lombet A, Planque N, Bleau A, Li CL, Perbal B: CCN3 and calcium signaling. Cell Commun Signal 2003, I(I): I.

37. Sjogren $S$, Inganas $M$, Norbert $T$ : The $\mathbf{p} 53$ gene in breast cancer; prognostic value of complemantary DNA sequencing versus immunohistochemistry. J Natl Cancer Inst 1988, 88:I73-182.

38. Takenaga K, Nakamura Y, Sakiyama S, Hasegawa Y, Sato K, Endo H Binding of pEL98 protein, an S100-related calcium-binding protein, to non-muscle tropomyosin. I Cell Biol 1994, I 24:757-768.

39. Endo H, Takenaga K, Kanno T, Satoh H, Mori S: Methionine aminopeptidase $\mathbf{2}$ is a new target for the metastasis-associated protein, SI O0A4. J Biol Chem 2002, 277:26396-26402.

40. Li CL, Martinez V, He B, Lombet A, Perbal B: A role for CCN3 (NOV) in calcium signaling. Mol Pathol 2002, 55:250-26I.

4I. Takenaga K, Nakamura Y, Endo H, Sakiyama S: SI 00A4, a mediator of metastasis. Jpn J Cancer Res 1994, 85:83 I-839.

42. Ambartsumain N, Kligelhofer J, Grigorian M, Christensen C, Kriajevska M, Tulchinsky E, Georgiev G, Berezin V, Bock E, Rygaard J, Cao R, Cao Y, Lukanidin E: The metastasis associated Mts I (SI 00A4) protein could act as an angiogenic factor. Oncogene 200I, 20:4685-4695.

43. Novitskaya V, Grigorian M, Kriajevaska M, Tarabykina S, Bronstein I, Berezin V, Bock E, Lukanidin E: Oligomeric forms of metastasis related Mts I (SIO0A4) protein stimulate neuronal differentation in cultures of rat hippocampal neurons. J Biol Chem 2000, 275(52):4I278-4I286.

44. Belot N, Pochet R, Heizmann CW, Kiss R, Decaestekor C: Extracellular SIO0A4 stimulates the migration rate of astrocytic tumor cells by modifying the organization of their actin cytoskeleton. Biochem Biophys Acta 2002, I 600:74-83.

45. Takenagoa K, Nakanishi H, Wada K, Suzuki M, Matsuzuki O, Matsuura $A$, Endo $\mathrm{H}$ : Increase expressiom of SI00A4, a metastasisassociated gene, in human colorectal adenocarcinomas. Clin Cancer Res 1997, 3:2309-23 I6.

46. Gongoll S, Peters G, Mengel M, Piso P, Klempnauer J, Kreip H, Von Wasielewski R: Prognostic significance of calcium-binding protein SIO0A4 in colorectal cancer. Gastroenterology 2002, | 23(5): |478-|484.

47. Nakamura T, Ajiki T, Murao S, Kamigaki T, Maeda A, Ku Y, Kuroda Y: Prognostic significance of SI00A4 expression in gallbladder cancer. Int I Oncol 2002, 20(5):937-4|.

48. Davies BR, O'Donnell M, Durkan GC, Rudland PS, Barraclough R, Neal DE, Mellon JK: Expression of SI O0A4 protein is associated with metastasis and reduced survival in human bladder cancer. J Pathol 2002, I 96(3):292-9.

49. Ninomiya I, Ohat T, Fushida S, Endo y, Hashimoto T, Yagi M, Fujimura T, Nishimura G, Tani T, Shimizu K, Yonemura Y, Heizmann CW Schafer BW, Sasaki T, Miwa K: Increased expression of SI 00A4 and its prognostic significance in esophageal squamous cell carcinoma. Int J Oncol 200I, I 8(4):7I5-20.

50. Platt-Higgins AM, Renshaw CA, West CR, Winstanley JH, De Silva RS, Barraclough R, Rudland PS: Comparison of the metastasis- inducing protein SI 00A4 (p9ka) with other prognostic markers in human breast cancer. Int J Cancer 2000, 89:198-208.

51. Rudland PS, Platt-Higgins A, Renshawa C, West CR, Winstanley JH, Robertosn L, Barraclough R: Prognostic significance of the metastasis-inducing protein S $100 \mathrm{~A} 4$ (p9Ka) in human breast cancer. Cancer Res 2000, 60(6): 1595-603.

52. Kimura K, Endo Y, Yonemura Y, Heizmann CW, Schafer BW, Watanabe $Y$, Sasaki T: Clinical significance of SI O0A4 and E-cadherinrelated adhesion molecules in non-small cell lung cancer. Int | Oncol 2000, I6(6): | |25-3|

53. Ember CR, Ember M: Encylopedia of medical anthropology: Health and illness in the world's cultures topics. Springer; 2004:10-44.

54. Sara Rosenthal M: Stopping cancer at the source. Trafford Publishing; 200 I:10-22.

55. Miley WM: The psychology of well being. Praeger/Greenwood 1999:190-210.

56. Ginex PK, Frazzitta BL, Bains MS, Hanson J: I00 Questions \& Answers about esophageal eancer. Jones and Bartlett Publishers; 2005:2-12

57. Park WS, Oh RR, Kim YS, Shin MS, Lee SH, Yoo NJ, Lee JY: Absence of mutations in the kinase domain of the Met gene and frequent expression of Met and HDF/SF protein in primary gastric carcinoma. APMIS 2000, I08:195-200.

58. Davies BR, Davies MPA, Gibbs FEM, Barraclough R, Rudland PS: Induction of the metastatic phenotype by transfection of a benign rat mammary epithelial cell line with the gene for p9Ka, a rat calcium-binding protein, but not with the oncogene EJ-ras-I. Oncogene 1993, 8:999-1008.

59. Kriajevska M, Cardenas MN, Grigorian MS, Ambartsumain NS, Georgiev GP, Lukanidin EM: Non-muscle myosin heavy chain as a possible target for protein encoded by metastasisrelated mts-I gene. J Biol Chem 1994, 269: I9679-19682.

60. Cho YG, Nam SW, Kim TY, Kim YS, Kim CJ, Park JY, Lee JH, Kim HS, Lee JW, Park CH, Song YH, Lee SH, Yoo NJ, Lee JY, Park WS: Overexpression of SI00A4 is closely related to the aggressiveness of gastric cancer. APMIS 2003, I I I:539-545.
Publish with Biomed Central and every scientist can read your work free of charge

"BioMed Central will be the most significant development for disseminating the results of biomedical research in our lifetime. "

Sir Paul Nurse, Cancer Research UK

Your research papers will be:

- available free of charge to the entire biomedical community

- peer reviewed and published immediately upon acceptance

- cited in PubMed and archived on PubMed Central

- yours - you keep the copyright
BioMedcentral 